\title{
Weed dynamics in grain sorghum-grass intercropped systems ${ }^{1}$
}

\author{
Dinâmica de plantas daninhas em sistemas de consórcio de sorgo granífero- \\ braquiárias
}

\author{
Joilson Sodré Filho ${ }^{2}$, Robélio Leandro Marchão ${ }^{3 *}$, Arminda Moreira de Carvalho ${ }^{3}$ e Ricardo Carmona ${ }^{2}$
}

\begin{abstract}
The aim of this study was to assess the influence of short-season sorghum-grass intercropped systems on weed population dynamics. The integrated systems consisted of sorghum grown at two row spacings $(0.50 \mathrm{~m}$ and $0.70 \mathrm{~m}$ ), intercropped with palisade grass or Congo grass. We also used sole crops of sorghum, palisade grass, Congo grass and a fallow to serve as a reference for spontaneous vegetation. The experiment was conducted in 2010 and 2011 at Planaltina (Federal District) in Brazil. Weed populations and weed dry matter were assessed during the short season and during the succession soybean cycle. The weed soil seed bank was sampled in both years of the study. Sorghum at a row spacing of $0.50 \mathrm{~m}$ intercropped with Congo grass reduced the Ageratum conyzoides population. The Tridax procumbens seed bank in the soil was reduced by using sorghum at a the row spacing of $0.70 \mathrm{~m}$, whether intercropped or not. Planting palisade grass during the short season reduced Digitaria sanguinalis in the soil seed bank. Planting palisade grass or Congo grass as a sole crop or intercropped reduced the number of weed seeds in the soil, showing that these species can be recommended for integrated weed management in intercropped systems.
\end{abstract}

Key words: Urochloa brizantha. Urochloa ruziziensis. Soil seed bank. No-tillage. Integrated crop-livestock system.

\begin{abstract}
RESUMO - Objetivou-se avaliar a dinâmica de plantas daninhas influenciada pelo cultivo de sorgo na safrinha em dois espaçamentos entre linhas $(0,5$ e $0,7 \mathrm{~m})$ consorciado com braquiária ruziziensis e capim-marandu e em cultivo solteiro. O experimento foi conduzido em Planaltina, DF, nas safras 2010/2011 e 2011/2012 e as avaliações realizadas durante o ciclo do sorgo na safrinhas e na soja em sucessão. Foram avaliadas a população e a matéria seca de plantas daninhas e o banco de sementes no solo durante os dois anos agrícolas. O sistema de sorgo consorciado com braquiária ruziziensis no espaçamento de $0,50 \mathrm{~m}$ reduziu a população de Ageratum conyzoides entre os anos agrícolas. A quantidade de sementes viáveis de Tridax procumbens no solo foi reduzida no sistema com sorgo cultivado no espaçamento 0,70 $\mathrm{m}$, independente de estar consorciado ou não. O cultivo solteiro de capim-marandu na safrinha diminuiu o banco de sementes de Digitaria sanguinalis no solo. Sistemas de cultivo em safrinha com a presença de capim-marandu ou braquiária ruziziensis, solteiros ou em consórcio, apresentaram menor número de sementes de plantas daninhas viáveis no solo, indicando que essas espécies podem ser inseridas em sistemas consorciados ou em sucessão visando ao manejo integrado no sistema plantio direto.
\end{abstract}

Palavras-chave: Urochloa brizantha. Urochloa ruziziensis. Banco de sementes no solo. Sistema plantio direto. Integração lavoura-pecuária.

\footnotetext{
*Autor para correspondência

${ }^{1}$ Recebido para publicação 06/02/2014; aprovado em 12/09/2014

Extraído da Tese de Doutorado do primeiro autor no Programa de Pós-Graduação em Agronomia da FAV/UNB, com financiamento de bolsa pelo REUNI e do projeto pela EMBRAPA

${ }^{2}$ Faculdade de Agronomia e Medicina Veterinária/ICC Sul, Universidade de Brasília, Campus Darcy Ribeiro, Asa Norte, Brasília-DF, Brasil, 70.910-970, sodrefilho@hotmail.com,rcarmona@unb.br

${ }^{3}$ Embrapa Cerrados, BR 020, Km 18, Caixa Postal 08223, Planaltina-DF, Brasil, 73.310-970, robelio.marchao@embrapa.br, arminda.carvalho@ embrapa.br
} 


\section{INTRODUCTION}

One of the most serious problems in intensive tropical agriculture, especially under no-tillage, is the presence of weed species that are difficult to manage. Since weeds are higher adapted to their environment, herbicideresistant biotypes can rapidly become established. Furthermore, although herbicides can be used in an integrated management system, they should not be used as the only method of control (RIZZARDI et al., 2003).

Controlling weeds when sowing crops after desiccation can be important in maintaining crop competitiveness. However, this kind of control is efficient only for weeds that are already established, allowing new weeds to emerge during the crop cycle. Silva et al. (2009) observed reductions of up to $73 \%$ in soybean yields due to the presence of weeds during the entire crop cycle. One way of keeping weed populations below the level at which economic damage results is to use the crop itself, leaving crop residues on the soil surface, a strategy for reducing weed populations rather than eliminating weed species altogether.

Some crops can be used to provide a mulch for controlling weeds in agroecosystems. One option is sorghum, a grass with potential for short-season cropping that can help form a mulch that is effective for suppressing invasive weeds, mainly due to its allelochemical root exudates (DAYAN, 2006). The efficiency of this method depends on the volume of mulch produced, but some sorghum genotypes can achieve a 74\% reduction in invasive weeds (NOCE et al., 2008).

Palisade grass is another option that can be grown in the short-season to cut weed infestations (BRAZ et al., 2006). Correia, Durigan and Espanhol (2011) reported the positive effect of using palisade grass residues to control weeds in succession cropping, mainly under no-tillage, in addition to chemical control. Another forage crop widely used in integrated systems is Congo grass, described by Adegas, Voll and Gazziero (2011) as an efficient competitor with weed species.

Intercropping forage species with annual crops is an integrated system for avoiding weed competition, since the forage species competes with the weeds (COBUCCI; PORTELA, 2003; SEVERINO; CARVALHO; CHRISTOFFOLETI, 2006), in conjunction with the allelopathic potential of most forage species. Although these systems are important for integrated weed control, there is little information in the literature on the effects of integrated or intercropped systems on weed dynamics (IKEDA et al., 2007).

Knowledge of the weed seeds dormant in the soil in any agricultural system is fundamental to gain a better understanding of the history of local management techniques, and for planning future control strategies (SEVERINO; CARVALHO; CHRISTOFFOLETI, 2006; SODRÉ FILHO et al., 2008). Information on infestation dynamics is scarce, mainly because we know little of the relationship between the soil seed bank and emergent flora (ISAAC; GUIMARÃES, 2008).

Therefore, the aim of this study was to assess the population dynamics of weeds (emergent flora and soil seed bank) in sorghum crops grown in the short season in succession with soybean, at two row spacings and as a sole crop or intercropped with palisade grass and Congo grass.

\section{MATERIAL AND METHODS}

The experiment was conducted at in Planaltina (Federal District), Brazil, during the 2010/2011 and 2011/2012 agricultural years, in an experimental area at grid reference $15^{\circ} 35^{\prime} 54.6^{\prime \prime} \mathrm{S}, 47^{\circ} 42^{\prime} 29.2^{\prime \prime} \mathrm{W}$, and with elevation 1,008 m. The soil is a Typic Acrustox (Latossolo Vermelho according to the Brazilian Soil Classification System). The experimental design consisted of randomized complete blocks with four replications.

During these two agricultural years, we assessed the soil seed bank and weed dynamics on the basis of the flora emerging during the growth of the sorghum intercropped with forage species in the short season, and in a succession soybean crop in the summer. The shortseason crop systems studied were: (i) Sorghum sole crop at a row spacing of $0.50 \mathrm{~m}$; (ii) Sorghum at a row spacing of $0.50 \mathrm{~m}$ intercropped with palisade grass; (iii) Sorghum at a row spacing of $0.50 \mathrm{~m}$ intercropped with Congo grass; (iv) Sorghum sole crop at a row spacing of $0.70 \mathrm{~m}$; (v) Sorghum at a row spacing of $0.70 \mathrm{~m}$ intercropped with palisade grass; (vi) Sorghum at a row spacing of $0.70 \mathrm{~m}$ intercropped with Congo grass; (vii) Palisade grass sole crop; (viii) Congo grass sole crop; (ix) Short-season soybean; (x) Fallow.

The plots measured $5 \times 8 \mathrm{~m}$ with a usable area of $28 \mathrm{~m}^{2}$, totaling $1,120 \mathrm{~m}^{2}$ of experimental area. The sorghum (Sorghum bicolor cv. BR 304) and soybean (Glycine max BRS Favorita RR) in the shortseason treatment were sown using a seeder unit. The sorghum was sown under no-tillage on 3/15/2010 and on 3/17/2011, with 18 and 22 seeds per meter, at row spacings of $0.50 \mathrm{~m}$ and $0.70 \mathrm{~m}$ respectively, aiming to produce a plant population of 300,000 plants per hectare. In the short-season soybean system, sown on the same date as the sorghum, we used a row spacing of $0.50 \mathrm{~m}$ and 18 seeds per meter. The palisade grass (Urochloa brizantha cv. Marandu) and Congo grass 
(Urochloa ruziziensis R.Germ \& C.M Evrard) were sown at the same time as the sorghum, using an adapted seeder unit with a box for distributing the forage seeds, set up to plant $14 \mathrm{~kg}$ of pure seeds (germination $80 \%$ ) per hectare, at a row spacing of $0.25 \mathrm{~m}$. In plots with short-season soybean (between growing seasons), at 15 DAE (days after emergence), weeds were controlled by applying glyphosate $\left(1,800 \mathrm{~g} \mathrm{ha}^{-1}\right.$ and solution volume of $400 \mathrm{~L} \mathrm{ha}^{-1}$ ). Insect pests and diseases were controlled where necessary in accordance with the technical recommendations for sorghum and soybean crops.

On $9 / 23 / 2010$ and $9 / 15 / 2011$, the plots were dried out for planting the succession soybean crop on the same day, applying the glyphosate $\left(1,800 \mathrm{~g} \mathrm{ha}^{-1}\right.$ and solution volume of $400 \mathrm{~L} \mathrm{ha}^{-1}$ ) for controlling the remaining vegetation consisting of weeds and grasses. On 10/13/2010 and 10/11/2011, soybean cv. BRS Favorita RR was sown using a seeder unit set to 22 seeds per meter and row spacing of $0.50 \mathrm{~m}$, aimed at producing a final plant population of 320,000 plants per hectare. At $28 \mathrm{DAE}$, all seedling plots were treated with glyphosate $\left(1.800 \mathrm{~g} \mathrm{ha}^{-1}\right.$ and solution volume of $\left.300 \mathrm{~L} \mathrm{ha}^{-1}\right)$. In order to harvest early, at $128 \mathrm{DAE}$ (phenological stage R8), the soybean was desiccated using paraquat dichloride (400 $\mathrm{g} \mathrm{ha}^{-1}$ and solution volume of $200 \mathrm{~L} \mathrm{ha}^{-1}$ ).

Assessments of weed populations (emergent flora) were carried out at $30 \mathrm{DAE}$ for all sorghum treatments, and at 19 DAE for the soybean treatments. Assessments of the soybean crops were carried out prior to the critical period of competition and interference (stage V2.5) and before applying the glyphosate to control invasive weeds. To sample the emergent flora, we used an iron square (50 $\mathrm{x} 50 \mathrm{~cm}$ ) dropped at random in four locations within each plot, giving a total sampled area of $1 \mathrm{~m}^{2}$. Then we identified and counted each species within the iron square. Finally the the aboveground biomass of weeds were collected and placed in an oven set to $60{ }^{\circ} \mathrm{C}$ for $72 \mathrm{~h}$ in order to obtain the dry weight.

On 6/14/2010 and 6/13/2011, before harvesting the sorghum, we collect disturbed soil samples to characterize the soil weed seed bank, removing ten subsamples per plot in the $0-20 \mathrm{~cm}$ layer using a Dutch auger (diameter of $5 \mathrm{~cm}$ and $20 \mathrm{~cm}$ in height). The subsample soil was homogenized to obtain a composite soil sample for each system. After drying at ambient temperature for five days, $1,000 \mathrm{~g}$ soil was placed on plastic trays $(21 \mathrm{x} 35$ $\mathrm{x} 6 \mathrm{~cm}$ ) and randomly distributed inside the greenhouse. Observations on the emergence of seedlings were made at least every seven days over a period of 12 months. The probable number of seeds per square meter at a depth of $20 \mathrm{~cm}$ was obtained using the method proposed by Monquero and Christoffoleti (2003), as follows: (number of seedlings/sample weight in $\mathrm{kg}$ ) = (number of nondormant seeds $\mathrm{m}^{-2} 280 \mathrm{~kg}$ ), based on the assumption that a cubic meter of soil with a depth of $20 \mathrm{~cm}$ weighs on average $280 \mathrm{~kg}$ (mean soil density of $1.3 \mathrm{~g} \mathrm{~cm}^{-3}$ ).

With the aim of reducing the dimensions of the data, we calculated the rate of change of the infesting population in each cropping system by comparison with the fallow plot, for each assessment time of year (short season, growing season) and also to the soil seed bank assessments. To calculate the rate of change, we used the model $\exp (\beta)$, where $\beta$ is the parameter associated with each treatment. The parameters were obtained from generalized linear models (GLM) associated with Poisson regression and in some specific cases, using Zero-inflated Poisson (ZIP) regression. The criteria used for the model selection were the chi-square $\left(\chi^{2}\right)$ statistic for ZIP model and the deviance for simple Poisson model. After obtain the estimates of parameters and their standard errors, we aplly the t-test for multiple comparisons with the fallow as a reference. In order to analyze the dry matter values of the emergent flora, an analysis of variance with repeated measurements (ANOVA) was applied to evaluate the effects of cropping systems, growing season and the interaction between these two factors. The t-test at 5\% probability was used to the comparisons. All steps were done using SAS 9.2 (SAS INSTITUTE, 2009).

\section{RESULTS AND DISCUSSION}

In all the assessment we identified 22 weed species, as follows in decreasing order of occurrence: Bidens pilosa (22.39\%), Chamaesyce hirta (14.60\%), Richardia brasiliensis (12.41\%), Ageratum conyzoides (6.34\%), Eleusine indica (4.55\%), Digitaria sanguinalis (4.49\%), Tridax procumbens (3.70\%), Emilia fosbergii (3.60\%), Gnaphalium spicatum (2.57\%), Rhynchelytrum repens (2.19\%), Commelina benghalensis (0.99\%), Galinsoga parviflora $(0.91 \%)$, Conyza bonariensis $(0.40 \%)$, Brachiaria decumbens (0.29\%), Euphorbia heterophylla (0.18\%), Amaranthus deflexus $(0.14 \%)$ and Oxalis corniculata $(0.09 \%)$. Other species of minor importance in agronomic terms occurred at lower frequencies, as follows: Cenchrus echinatus, Sonchus oleraceus, Ipomoea grandifolia, Brachiaria plantaginea and Portulaca oleracea. We observed a predominance of large-leaved species, and according to Concenço et al. (2011), large-leaved weeds are predominant in no-tillage areas, probably due to selection factors linked to the herbicides commonly used.

While the soybean was growing, there were respective drops of $78.38 \%$ and $63.48 \%$ in the populations of Ageratum conyzoides and Chamaesyce hirta, in the sorghum system at $0.50 \mathrm{~m}$ row spacing + Congo grass 
(Figures 1 e 2). This system also showed a $40.24 \%$ drop in the population of Ageratum conyzoides between agricultural years (Figure 3 ). This drop could be related to the physical effect of the mulch, since on desiccating the Congo grass and palisade grass prior to sowing the soybean, Monquero et al. (2010) observed that the mulch stayed longer over the soil after the soybean emerged, reducing the emergence of new weeds. The population of Eleusine indica also decreased to $23.49 \%$ in all crop systems during the growing period (Figure 4).

Figure 1 - Change (\%) in the population of Ageratum conyzoides, in each system during the 2010/2011 and 2011/2012 summer growing seasons

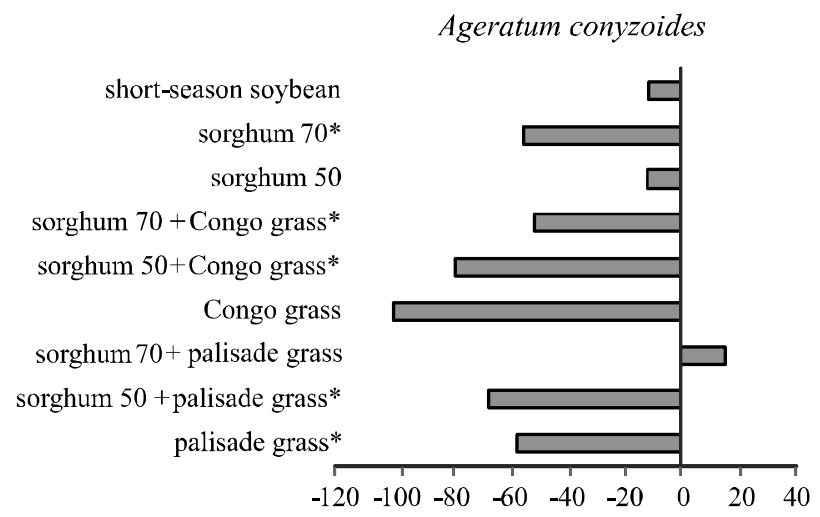

${ }^{(*)}$ Systems that showed a significant difference in comparison to the fallow treatment in both years

Figure 2 - Change (\%) in the population of Chamaesyce hirta, in each system during the 2010/2011 and 2011/2012 summer growing seasons

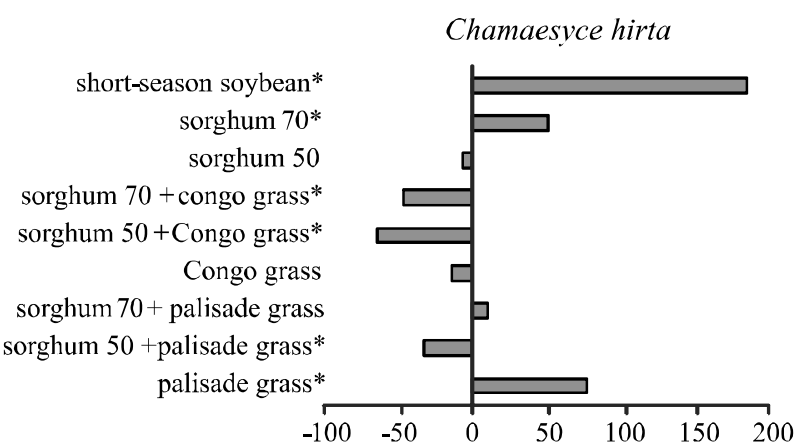

${ }^{(*)}$ Systems that showed a significant difference in comparison to the fallow treatment in both years

In terms of the weed seed bank in the soil, there was in general a drop in the emergent flora between the agricultural years (Figure 5), especially in Ageratum conyzoides which fell by $64.94 \%$ (Figure 3 ). The population density and composition of a weed community is heavily influenced by the type and presence of mulch on the soil, and the density of seeds in the bank can be significantly reduced in the no-tillage and pasture rotation systems (IKEDA et al., 2007). The treatments that showed a significant difference by comparison with the fallow treatment were the sole Congo grass and palisade grass crops. Palisade grass cropping in the interval between growing seasons resulted, on average, in a drop of $82.76 \%$ in the number of viable Ageratum conyzoides seeds.

In regard to Bidens pilosa, considered one of the most problematic weeds in the no-tillage system, the sole palisade grass and Congo grass systems and the

Figure 3 - Change (\%) in soil seed bank of Ageratum conyzoides in each system over the two years of assessment

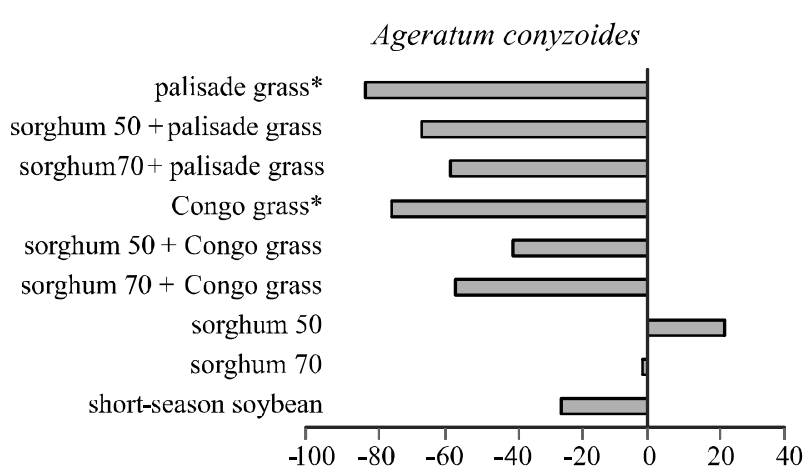

${ }^{(*)}$ Systems that showed a significant difference in comparison to the fallow in both years

Figure 4 - Change $(\%)$ in the population of Eleusine indica, in each system during the 2010/2011 and 2011/2012 summer growing seasons

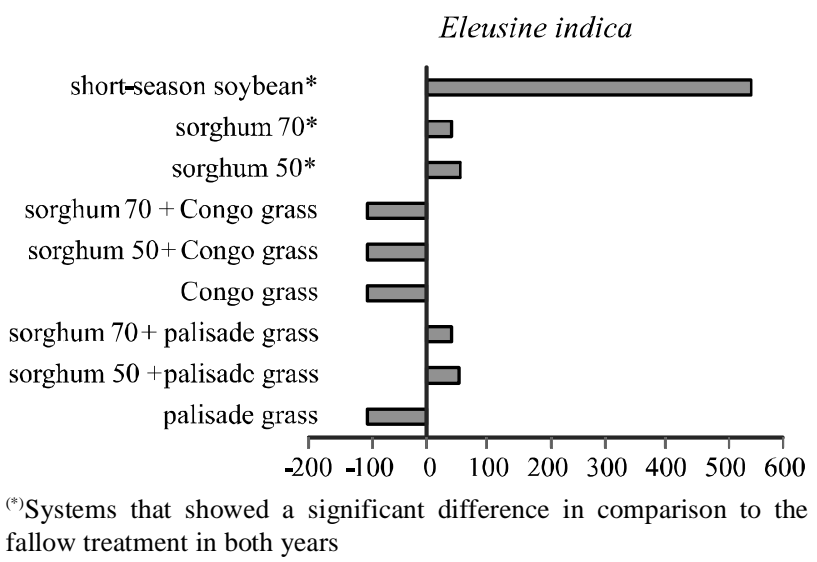


intercropped sorghum ( 0.50 and $0.70 \mathrm{~m}$ row spacing) showed a significant drop in weed populations by comparison with the fallow treatment (Figure 6). In terms of the successive agricultural years, in 2010 we observed that, on average, the quantity of viable Bidens pilosa seeds in the soil was six times greater than in 2011. In our assessments during the growing season, we also observed a significant drop in this species from one year to the next, especially in the intercropped systems. The drop from one year to another is probably due to the physical barrier presented by the mulch, preventing the emergence of seedlings and impeding the dispersal of weed seeds over the cropped area. In the sole palisade grass crop, the occurrence of Digitaria sanguinalis seeds in the soil dropped by an average $82.20 \%$ by comparison with the fallow treatment, and in the first year, we obtained an average of $50.0 \%$ more cases of viable Digitaria sanguinalis seeds than in the second year under the same system (Figure 7).

Figure 5 - Change (\%) in the weed community in each system over the two years of assessment

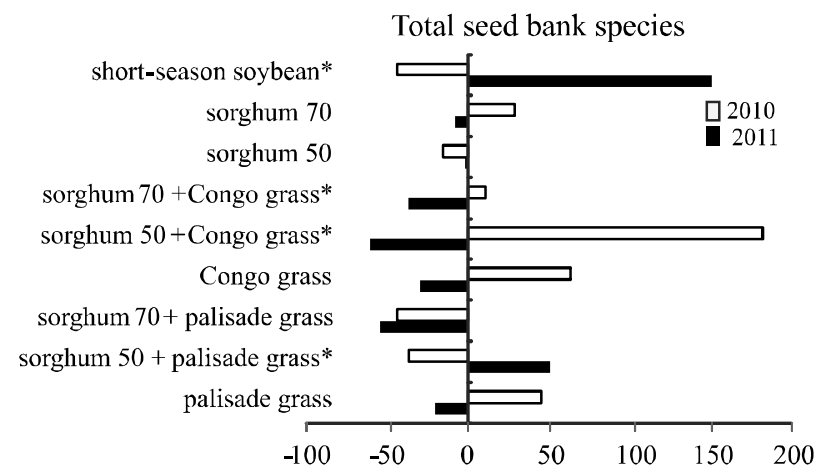

${ }^{(*)}$ Systems that showed a significant difference in comparison to the fallow in both years

Figure 6 - Change (\%) in the population of Bidens pilosa, in each system during the 2010/2011 and 2011/2012 summer growing seasons

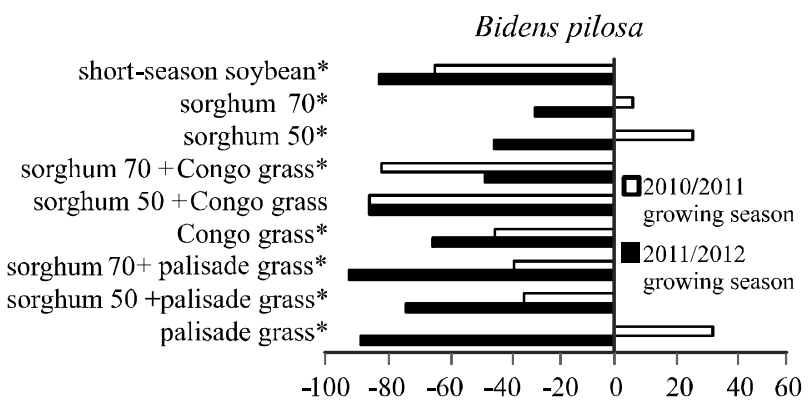

${ }^{(*)}$ Systems that showed a significant difference in comparison to the fallow treatment in both years
Figure 7 - Change (\%) in Digitaria sanguinalis soil seed bank in each system over the two years of assessment

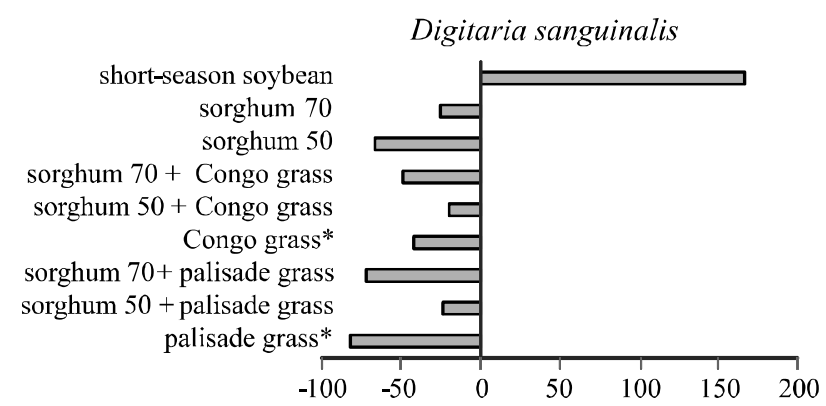

${ }^{(*)}$ Systems that showed a significant difference in comparison to the fallow in both years

An overall analysis of the species' communities in the soil seed bank shows that they vary according to the year and the system (Figure 5), evidence that there is no isolated effect of the farming system itself, which is dependent on the year and possibly on the climatic conditions of each agricultural year (Figure 8). There are other determining factors, such as the accumulation of mulch and its resistance to decomposition, as well as the characteristics of the cropped species, such as production of dry matter and allelochemicals, and the growth habit.

Figure 8 - Monthly rainfall ( $\square$ ) and average temperature $(\bullet)$ for the experimental period of the years 2010/2011 (a) and 2011/2012 (b) in Planaltina, DF, Brazil

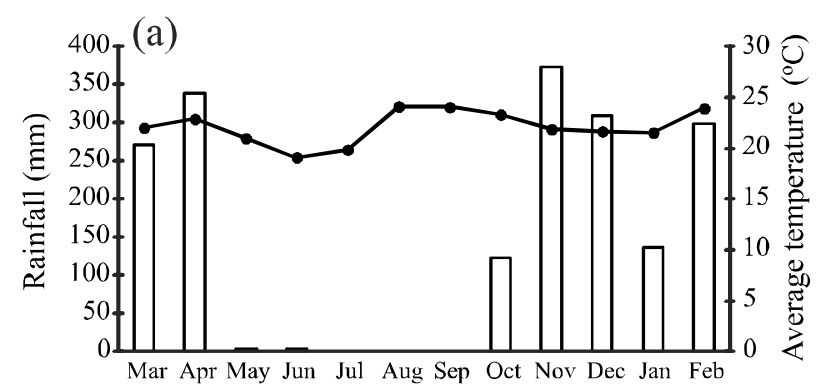

$2010 / 2011$

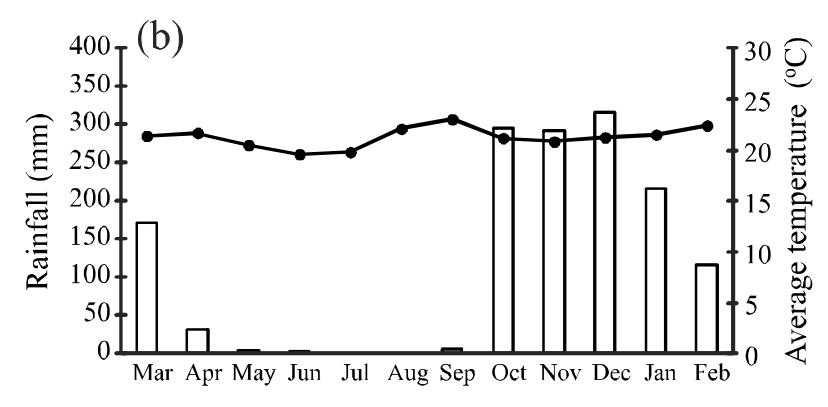

$2011 / 2012$ 
In general, systems involving signal grasses intercropped or as sole crops presented the lowest number of viable seeds in the soil. Whether grown as a sole crop or intercropped, sorghum was effective in reducing the emergence of Tridax procumbens (Figura 9). Sole cropping of Congo grass reduced occurrence in the soil of the seeds of this species by an average $77.58 \%$.

The fallow treatment had the greatest number of viable seeds in the soil. According to Correia, Durigan and Espanhol (2011), allowing the development of spontaneous species during autumn/winter is responsible for the increase in the soil seed bank. Uncovered soil facilitates the ingress of weed diaspores, boosting infestation by the seeds of this type of plant, a process that is hampered by covering the area (SILVA; DIASFILHO, 2001). According to these authors, the solution is a residual mulch to keep the weed population low and stable. This covering can be even more effective if the mulch has allelopathic properties (SODRÉ FILHO et al., 2008; TREZZI; VIDAL, 2004). Thus, the weed population will emerge in discrete and consecutive waves during the year (RIZZARDI et al., 2003; TREZZI et al., 2006), and the allelopathic effect of the residues distributed over this period remains in place. According to Nunes et al. (2010), if the chemical control of plant covers is successful, forming a layer of mulch uniformly distributed over the soil, the emergent weed population density tends to be lower. However, Monquero et al. (2010) reported that after the desiccation of the palisade
Figure 9 - Change (\%) in Tridax procumbens soil seed bank in each system over the two years of assessment

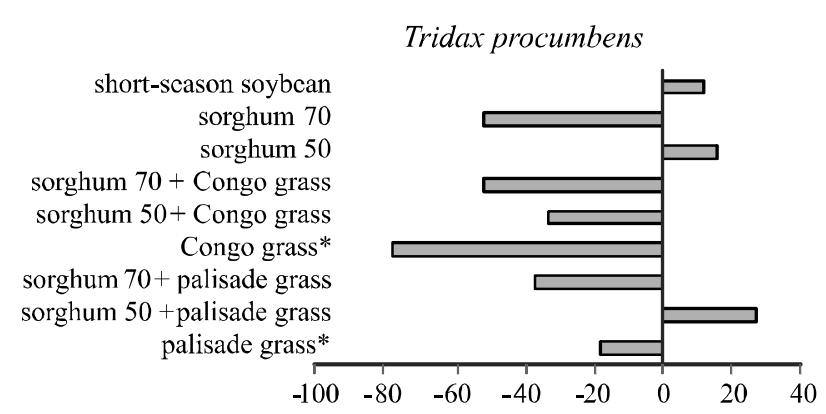

${ }^{(*)}$ Systems that showed a significant difference in comparison to the fallow in both years

grass and Congo grass used as cover plants, some soil seed bank species may cease to be dormant due to the penetration of light as the mulch provided by these grasses decomposes, changing the moisture content, luminosity and temperature of the soil, the main elements that affect seed dormancy and germination.

In terms of weed dry matter, in the assessments during the soybean cycle there was a significant difference between the agricultural years, with a drop in weed dry matter from the first to the second year (Table 1). Although similar chemical control was implemented in both years, including the use of the same herbicide at the same time of

Table 1 - Aboveground biomass of emergent flora (weed dry matter - $\mathrm{kg} \mathrm{ha}^{-1}$ ) for the short growing season and in succession soybean, and dry matter production for short-season systems (Planaltina, DF, Brazil, 2010 and 2011)

\begin{tabular}{lcc}
\hline \multicolumn{1}{c}{ Crop systems } & Short season & Summer \\
\cline { 2 - 3 } & (at sorghum growth) & (at succession soybean) \\
\hline Sorghum 0.50 m & $206.80 \mathrm{~b}^{(1)}$ & $196.56 \mathrm{ab}$ \\
Sorghum 0.50 m intercropped with palisade grass & $85.21 \mathrm{de}$ & $69.06 \mathrm{e}$ \\
Sorghum 0.50 m intercropped with Congo grass & $59.75 \mathrm{e}$ & $41.35 \mathrm{de}$ \\
Sorghum 0.70 m sole crop & $148.98 \mathrm{bc}$ & $145.31 \mathrm{bc}$ \\
Sorghum 0.70 m intercropped with palisade grass & $87.14 \mathrm{cde}$ & $82.71 \mathrm{de}$ \\
Sorghum 0.70 m intercropped with Congo grass & $80.86 \mathrm{de}$ & $56.04 \mathrm{cde}$ \\
Palisade grass sole crop & $94.82 \mathrm{cde}$ & $169.17 \mathrm{bcd}$ \\
Congo grass sole crop & $102.81 \mathrm{cde}$ & $63.13 \mathrm{e}$ \\
Short-season soybean & $142.83 \mathrm{~cd}$ & $396.98 \mathrm{a}$ \\
Fallow & $274.03 \mathrm{a}$ & $213.23 \mathrm{ab}$ \\
CV (\%) & 48.98 & 20.46 \\
Mean of 2010/2011 agricultural year & $125.49 \mathrm{a}$ & $255.27 \mathrm{a}$ \\
Mean of 2011/2012 agricultural year & $140.92 \mathrm{a}$ & $31.44 \mathrm{~b}$ \\
\hline
\end{tabular}

${ }^{(1)}$ Means followed by the same letter in the columns did not differ in the t-test at $5 \%$ probability 
year, this drop could have been due to the accumulation of residues over the soil, adding to the effect of the mulch's physical control, accumulating from one year to another.

The summer soybean crop grown under the shortseason soybean residues showed a high quantity of weed dry matter $\left(396,98 \mathrm{~kg} \mathrm{ha}^{-1}\right.$ - Table 1$)$, even though chemical weed control was used during the short season in accordance with the technical recommendations for the crop. Such a result underlines the importance of crop rotation, even in succession farming, demonstrating that growing soybean in both the main and short seasons leads to a gradual increase in invasive weeds. The sorghum produced similar results when grown as a sole crop, since it was not able to produce a mulch that effectively covered the soil. Lower values of weed dry matter in the assessments during the soybean crop cycle were observed in sorghum-grass intercropped systems, irrespective of the spacing and species used.

Growing Congo grass in the short season was also of interest since it showed low weed dry matter values $\left(63,13 \mathrm{~kg} \mathrm{ha}^{-1}\right)$, on a par with intercropped systems. The growth habit of Congo grass, together with the production of $5,620 \mathrm{~kg} \mathrm{ha}^{-1}$ dry matter, although relatively low by comparison with the intercropped systems and the sole sorghum crop, acted as a weed suppressant. Thus, in order to increase the sustainability of the no-tillage system, we recommend using a weed control method that is not based solely on the application of herbicides but rather boosting the positive effects produced by the crop itself.

Finally, we observed that the short-season crop systems affected the weed population, and this effect was more evident in intercropped systems or those using signal grasses as a cover plant. There are direct and indirect effects that influence the subsequent crop, confirming that the use of integrated control methods is beneficial for sustainability, since lower rates of herbicide can be used. Bidens pilosa and some species of Euphorbiaceae are described in the literature as resistant to herbicides, especially glyphosate, commonly used in areas under no-tillage. Therefore, the use of intercropping during the short season can be advantageous in managing this problem species, boosting the efficiency of control in these areas, especially in transgenic soybean crops.

\section{CONCLUSIONS}

1. The sorghum intercroped with Congo grass at $0.50 \mathrm{~m}$ row spacing reduces the population of Ageratum conyzoides;

2. Cropping systems including palisade grass or Congo grass, whether as sole crops in soybean sucession or intercropped in short season, result in a lower number of viable weed seeds in the soil and also reduce weed biomass from one agricultural year to another.

\section{ACKNOWLEDGEMENTS}

To EMBRAPA (Project $\mathrm{n}^{\circ}$ 02.08.01.003.00) for funding the research and REUNI/UnB for the doctorate scholarship awarded to the first author. To Luiz Felipe Corrêa for his help in field assessments.

\section{REFERENCES}

ADEGAS, F. S.; VOLL, E.; GAZZIERO, D. L .P. Manejo de plantas daninhas em milho safrinha em cultivo solteiro ou consorciado à braquiária ruziziensis. Pesquisa Agropecuária Brasileira, v. 46, n. 10, p. 1226-1233, 2011.

BRAZ, A. J. P. B. et al. Emergência de plantas daninhas em lavouras de feijão e de trigo após o cultivo de espécies de cobertura de solo. Planta Daninha, v. 24, p. 621-628, 2006.

COBUCCI, T.; PORTELA, C. M. O. Manejo de herbicidas no sistema Santa Fé e na braquiária como fonte de cobertura morta. In: KLUTHCOUSKI, J.; STONE, L. F.; AIDAR, H. Integração lavoura-pecuária. Santo Antônio de Goiás: Embrapa Arroz e Feijão, 2003. p. 443-458.

CONCENÇO, G. et al. Effect of long-term agricultural management systems on occurrence and composition of weed species. Planta Daninha, v. 29, n. 3, p. 515-522, 2011.

CORREIA, N. M.; DURIGAN, J. C.; ESPANHOL, M. Manejo de plantas daninhas em soja geneticamente modificada tolerante ao glyphosate. Pesquisa Agropecuária Tropical, v. 41, n. 2 , p. $242-247,2011$

DAYAN, F.E. Factors modulating the levels of the allelochemical sorgoleone in Sorghum bicolor. Planta, v. 224, n. 2, p.339-346, 2006.

IKEDA, F. S. et al. Banco de sementes no solo em sistemas de cultivo lavoura e pecuária. Pesquisa Agropecuária Brasileira, v. 42, n. 11, p. 1545-1551, 2007.

ISAAC, R. A.; GUIMARÃES, S. C. Banco de sementes e flora emergente de plantas daninhas. Planta Daninha, v. 26, n. 3, p. 521-530, 2008.

MONQUERO, P. A.; CHRISTOFFOLETI, P. J. Dinâmica do banco de sementes em áreas com aplicação frequente do herbicida glyphosate. Planta Daninha, v. 21, n. 1, p. 63-69, 2003.

MONQUERO, P. A. et al. Intervalo de dessecação de espécies de cobertura do solo antecedendo a semeadura da soja. Planta Daninha, v. 28, n. 3, p. 561-573, 2010.

NOCE, M. A. et al. Influência da palhada de gramíneas forrageiras sobre o desenvolvimento da planta de milho e das plantas daninhas. Revista Brasileira de Milho e Sorgo, v. 7, n. 3, p. $265-278,2008$. 
NUNES, A. S. et al. Formação de cobertura vegetal e manejo de plantas daninhas na cultura da soja em sistema plantio direto. Planta Daninha, v. 28, n. 4, p.727-733, 2010.

PEREIRA, F. A. R.; VELINI, E. D. Sistemas de cultivo no cerrado e dinâmica de populações de plantas daninhas. Planta Daninha, v. 21, n. 3, p. 355-363, 2003.

RIZZARDI, M. A. et al. Ajuste de modelo para quantificar o efeito de plantas daninhas e época de semeadura no rendimento de soja. Pesquisa Agropecuária Brasileira, v. 38, n. 1, p. 35-43, 2003.

STATISTICAL ANALYSIS SYSTEM - SAS. User's guide: second edition Version 9.2, Cary: SAS Institute, (CD-ROM) (2009).

SEVERINO, F. J.; CARVALHO, S. J. P.; CHRISTOFFOLETI, P. J. Interferências mútuas entre a cultura do milho, espécies forrageiras e plantas daninhas em um sistema de consórcio. II - Implicações sobre as espécies forrageiras. Planta Daninha, v. 24, n. 1 , p. $45-52,2006$.
SILVA, A. F. et al. Período anterior à interferência na cultura da soja-RR em condições de baixa, média e alta infestação. Planta Daninha, v. 27, n. 1, p. 57-66, 2009.

SILVA, D. S. M.; DIAS-FILHO, M. B. Banco de sementes de plantas daninhas em solo cultivado com pastagens de Brachiaria brizantha e Brachiaria humidicola de diferentes idades. Planta Daninha, v. 19, p. 179-185, 2001.

SODRÉ FILHO, J. et al. Culturas de sucessão ao milho na dinâmica populacional de plantas daninhas. Scientia Agraria, v. 9, n. 1, p. 7-14, 2008.

TREZZI, M. M.; VIDAL, R. A. Potencial de utilização de cobertura vegetal de sorgo e milheto na supressão de plantas daninhas em condição de campo: II - Efeitos da cobertura morta. Planta Daninha, v. 22, p. 1-10, 2004.

TREZZI, M. M. et al. Efeitos de resíduos da parte aérea de sorgo, milho e aveia na emergência e no desenvolvimento de plântulas de leiteiro (Euphorbia heterophylla) resistentes a inibidores da ALS. Planta Daninha, v. 24, n. 3, p. 443-450, 2006. 